\title{
Description of dental caries on mixed dentition stage of elementary school students in Cibeber Community Health Center
}

\author{
Andi Supriatna*, Rina Putri Noer Fadillah*, Azkya Patria Nawawi* \\ *Department of Dental Public Health Dental Education Program, \\ Faculty of Medicine Universitas Jenderal Achmad Yani, Indonesia
}

\begin{abstract}
Introduction: Dental and oral health can affect the quality of life as it relates to the general health condition. Dental and oral health problem that mostly found is dental caries. Dental caries mostly occurs in children in the mixed dentition stage. The mixed dentition stage occurs in elementary school-aged children, mark with malocclusions and tooth decays, that allows food retention as main cause of dental caries. The purpose of this study was to see the description of dental caries on mixed dentition stage of elementary school students in Cibeber Community Health Center. Methods: This research was a descriptive research with cross-sectional approach. The population in this study was elementary school students in Cibeber Community Health Center. The sampling method used was purposive sampling method. The caries profile was measured by deft index for deciduous teeth and DMFT index for permanent teeth were presented in tabular and diagrams. Results: The results of the study towards 272 elementary school students showed that the average value of deft index was 3.99 and DMFT index value was 1.26. This result can be caused since the location of the population was located in urban areas, with easy access to dental and oral health services and good tendencies towards the awareness of dental and oral health care. Conclusion: Dental caries of elementary school students in Cibeber Community Health Center based on (World Health Organization) guidelines by deft index was category as moderate and by DMFT index was classified low category.
\end{abstract}

Keywords: Dental caries, mixed dentition stage, elementary school students, deft/DMFT index.

P-ISSN 1979-0201, e-ISSN 2549-6212 Available from: http://jurnal.unpad.ac.id/pjd/article/view/14303

DOI: 10.24198/pjd.vol29no3.14303

Submission: Aug 2017 Publishing: Nov 2017

\section{INTRODUCTION}

Dental and oral health are an inseparable part of general health since it would affect the quality of life, as well appearance, speech and eating ability. However, problems that occur in oral health does not always considered for treatment. ${ }^{1}$ The most common dental and oral health problems in

Corresponding author: Andi Supriatna, Department of Dental Public Health Dental Education Program Faculty of Medicine Universitas Jenderal Achmad Yani, Jl. Ters. Jendral Sudirman, Jawa Barat, Indonesia; Email: andy_hsjsl@yahoo.com. 
Indonesia is dental caries. According to the report of Basic Health Research in $2007^{2}$, the prevalence of dental caries in Indonesia was at the amount of $46.5 \%$, which classified in high category especially in West Java, with the amount of $50.4 \%$. Based from the region, the prevalence of active caries in urban Indonesian communities was classified in high category, at the amount of $42 \%$, that required special attention from the various parties involved. ${ }^{2}$

Dental caries is the most common disease of the hard tissues caused by the activity of microorganisms as a result of fermented carbohydrates. The cause of caries is multifactorial, as interaction of four major factors: microorganisms, carbohydrate substrates, vulnerable tooth surfaces (host), and time factor. ${ }^{3}$ Dental caries is a disease that affects many children and adults, may affects deciduous and permanent teeth. ${ }^{4}$ The prevalence of dental and oral health problems based on the age category were about $10.4 \%$ of children aged $1-4$ years, $28.9 \%$ of children aged $5-9$ years and $25.2 \%$ of children aged $10-14$ years, and only about $25.8 \%$, $35.1 \%$, and $28.3 \%$ consecutively, were treated. ${ }^{5}$

Dental and oral health condition of children in recent decades has increased, but dental caries was still the most common oral health problem found in children worldwide. According to the WHO, the prevalence of dental caries in schoolaged children was ranged from $60-90 \%$ which was generally the same as in adults in most countries. ${ }^{6}$ A research conducted in Delhi, India towards 520 children aged $9-12$ years old that was published in 2011 showed that the prevalence of caries was in the value of $52.3 \%$, the average value of deft index of 9 years old children was 2.17 and in the age of 12 years old was $0.27 .^{7}$ The typical characteristic of children aged 6-14 years old is the critical age with special characteristic, which was the mixed dentition stage or the beginning stage of replacement from deciduous teeth into permanent teeth. ${ }^{4}$

Childhood period needs special attention, especially in the age of 6-9 years old. In the age of 6 years old, permanent molars usually begins to erupt and becoming more vulnerable towards caries exposure, while the age of 9 years old is a mixed dentition since the number of permanent and decidous teeth are almost the same, which are 14 permanent teeth and 10 deciduous teeth. ${ }^{8}$
Mixed dentition stage consists of three periods: transitional period, inter transitional period and second transitional period. Each period shows the state of the teeth which allows the food retentions to occur and difficult to be cleaned, leads to dental caries. ${ }^{9}$

Since the high prevalence of dental caries in elementary school children, caries prevalence surveys are needed, especially in the mixed dentition stage. The location chosen was Cibeber Community Health Center, which is one of the urban area in the city of Cimahi. The purpose of this study was to found out the description of dental caries on mixed dentition stage of elementary school students in Cibeber Community Health Center.

\section{METHODS}

The research type was descriptive quantitative research with cross sectional methods. The population in this research was the $3^{\text {rd }}$ grade elementary students in Cibeber Community Health Center from 7 elementary schools. The samples were chosen by purposive sampling technique. ${ }^{10}$ Dental caries assessment procedure began with submission of research permit application to the school and the provision of informed consent represented by the research subject's parents. Tools used in this research were deft/DMFT forms for intra oral examination results, cotton, mouth mirror, dental explorer, excavator, mask, gloves, alcohol on the concentration of $70 \%$, disinfectant, and flashlight.

The caries status data was obtained by examination using DMFT index on permanent teeth and deft index on deciduous teeth. The record that was used during inspection were $D$ (decayed) for the carious teeth, where the dental explorer tip was pointed to the cavity; M (Missing) for the revoked teeth due to caries, teeth extraction trace or presence of root residue; and F (Filling) for restored teeth. On the assessment of deciduous tooth, d (decayed) for carious teeth; e (exfoliated) for the revoked teeth due to caries, and teeth extraction trace or presence of root residue; $f$ (filling) for restored teeth; then summation was done to obtain the results or DMFT and deft values, and also to found out the DMFT and deft average value. 
The WHO deft/DMFT index calculation criteria were categorized as very low in the value of $0.0-1.1$; low in the value of 1.2-2.6; moderate in the value of 2.7-4.4; high in the value of 4.56.5; and very high in the value above 6.6.

\section{RESULTS}

The study conducted towards 272 elementary school students in the Cibeber Community Health Center, consisted of 144 male students and 128 female students. The frequency distribution of respondent characteristics was seen in Table 1. The results of deft/DMFT examination were arranged based on gender and average values, as presented in Table 2.

The Table 2 showed the description of each component of deft index, which were decay, exfoliated, and filling. In male students were found 506 decayed teeth, 41 exfoliated or extracted teeth, and 3 teeth that has been filled. In female students were found 479 decayed teeth, 54 exfoliated or extracted teeth, and 4 teeth that has been filled. The decay component amount on female students was found lower than male students. The average value of deft index on female students was 4.20 , having higher value than on male students, which was only 3.82 .
The results of DMFT examination towards elementary school students of Cibeber Community Health Center were presented in Table 3. From the Table 3 showed that the Decay component on female students were 172, was higher than male students, which were 154 . The Missing component on female students were 4 teeth, indicated that the normally extracted tooth or caries-caused extracted tooth were lower than male students, which were 6 teeth. The Filling component on female students were 3 teeth, lower than male students, which were 6 teeth. Therefore the average value of DMFT index on female students

Table 1. The frequency distribution of respondent characteristics based on gender in elementary school students of the Cibeber Community Health Center

\begin{tabular}{lcc}
\hline Elementary School & \multicolumn{2}{c}{ Gender } \\
\cline { 2 - 3 } (State Elementary School (SDN)/ & Male & Female \\
Islamic Elementary School (MI)) & 16 & 20 \\
\hline SDN 1 Cibeber & 7 & 14 \\
SDN 2 Cibeber & 26 & 17 \\
SDN 3 Cibeber & 11 & 16 \\
SDN 4 Cibeber & 45 & 36 \\
SDN Mandiri 1 Cibeber & 25 & 18 \\
SDN Mandiri 2 Cibeber & 14 & 7 \\
MI Baiturrahim Cibeber & 144 & 128 \\
\hline
\end{tabular}

Table 2. The results of deft examination towards elementary school students of Cibeber Community Health Center based on gender

\begin{tabular}{ccccccc}
\hline Gender & $\begin{array}{c}\text { Numbers of } \\
\text { respondent }\end{array}$ & d & e & F & $\begin{array}{c}\text { def } \\
\text { Total }\end{array}$ & $\begin{array}{c}\text { deft index average } \\
\text { value }\end{array}$ \\
\hline Male & 144 & 506 & 41 & 3 & 550 & 3.82 \\
Female & 128 & 479 & 54 & 4 & 537 & 4.20 \\
\hline
\end{tabular}

Table 3. The results of DMFT examination towards elementary school students of Cibeber Community Health Center based on gender

\begin{tabular}{ccccccr}
\hline Gender & $\begin{array}{c}\text { Numbers of } \\
\text { respondent }\end{array}$ & D & M & F & DMF & Total \\
\hline Male & 144 & 154 & 6 & 6 & 166 & 1.15 \\
Female & 128 & 172 & 4 & 3 & 179 & 1.39 \\
\hline
\end{tabular}

Table 4. The deft and DMFT index value on elementary school students of Cibeber Community Health Center

\begin{tabular}{lcccc}
\hline Population & $\begin{array}{c}\text { Numbers of } \\
\text { respondent }\end{array}$ & $\begin{array}{c}\text { def } \\
\text { Total }\end{array}$ & $\begin{array}{c}\text { DMF } \\
\text { Total }\end{array}$ & $\begin{array}{c}\text { Index average } \\
\text { deft }\end{array}$ \\
\hline $\begin{array}{c}\text { Elementary school (SD) of Cibeber Community Health } \\
\text { Center }\end{array}$ & 272 & 1087 & 345 & 3.99 \\
\hline
\end{tabular}


were 1.39 , higher than male students, which were 1.15. The deft and DMFT index value on elementary school students of Cibeber Community Health Center were presented in Table 4.

\section{DISCUSSION}

The results on the Table 1 showed that male respondent of the research was higher than female. Also the elementary school population that provided most respondent was from SDN Mandiri 1 Cibeber. The results from Table 2 and 3 present the deft and DMFT index on female students were higher than the male students. This result was in accordance with the study conducted by Lukacs ${ }^{12}$, which stated that the prevalence of dental caries on female was higher than on male, this happened due to sex hormone changes, biochemical composition, salivary flow rate, and also the earlier tooth eruption on female than male. This early eruption made the female tooth contact longer through the caries risk factors, such as host, saliva, microorganism, cariogenic food, and time. ${ }^{11}$ Another research conducted by Fujita et al. ${ }^{13}$ also showed the same results, where generally, female were tend of having higher dental caries prevalence rather than male on their young age. Besides of the early eruption, the high prevalence on female was also occurred due to sweet dietary habit tendency. ${ }^{12}$

According to WHO classification, the deft index result on elementary school students of Cibeber Community Health Center classified as moderate, which was 3.99. Whilst the DMFT index was classified as low, which was was 1.26 . This result showed that the $3^{\text {rd }}$ grade of elementary school students of Cibeber Community Health Center were already having the awareness of the importance of oral and dental health care, although still needed to be improved, due to the high amount of tooth decay especially on the deciduous teeth, which was found nearly on all respondent. This results was in accordance with the research conducted by Gayatri ${ }^{14}$ which found the high prevalence of dental caries on elementary school students in the city of Malang. This deft/ DMFT results have not reached the target of WHO in 2000, whereas the target of dental health care in 2010, amongst them, for the 5 years old children will having a $90 \%$ caries free-rate, and the severity of tooth decay (DMFT index) was as much as $1 .{ }^{13}$

Dental caries is a multifactorial disease, with several key factors which were host, cariogenic biofilm, fermentable carbohydrates, and time. Dental caries occurs due to inherent carbohydrates attached on the tooth surface that activates the cariogenic metabolism inside the plaque and produces the organic acids, especially the lactic acid and acetate acid. The organic acids formed from carbohydrates fermentation by the bacteria will caused the loss of tooth minerals and leads to dental hard tissue demineralization. ${ }^{14}$

The deft index on elementary school students of Cibeber Community Health Center have not reached the target of WHO due to the lack of knowledge, awareness, and independence of children on taking care of their health and hygiene. The elementary school-aged children, especially on the mixed dentition stage, are usually very dependent on their parents asumption. The lack of awareness and knowledge from the parents, and the incorret paradigm that the health of deciduous teeth doesn't need to be maintained because they will be replaced by permanent teeth, so dentist treatment isn't required for the children were the wrong assumption from parent. ${ }^{15}$ Another cause is a lot of cariogenic and high sugary snacks sold in the environment of the children's school, that makes the high exposure of deciduous teeth towards these cariogenic factors. A research conducted by Talibo et al. ${ }^{17}$ in 2016 toward $3^{\text {rd }}$ grade elementary school students showed that the student with high consumption of cariogenic snacks were having a higher dental caries. This condition makes the cummulation of the cariogenic materials on the tooth surface over time, therefore, an extra oral and dental care needed in this condition to avoided the occurrence of dental caries. ${ }^{16}$ The children also need to be given dental health education in order to improved their awareness and skill on maintaining their dental and oral hygiene. ${ }^{17}$

In this study, the low DMFT index results in the elementary school in Cibeber Community Health Center may caused by the location of the study population that close with the downtown area, with good accessibility of transportation, communication, information, and healthcare facility. In the urban area, the accessibility of transportation and communication are distributed more evenly, and therefore, makes urban people 
obtaining comprehensive (general and dental) healthcare. This condition makes the parents in the urban area are generally having better knowledge of maintaining the dental and oral hygiene of their children and also a better chance of having dental healthcare needed. ${ }^{15}$ The shortcomings of this study was a limited sample of research to described the occurrence of dental caries in elementary school-aged children in bigger area.

\section{CONCLUSION}

Dental caries of elementary school students in Cibeber Community Health Center based on (World Health Organization) guidelines by deft index was category as moderate and by DMFT index was classified low category.

\section{ACKNOWLEDGEMENT}

All authors are presenting gratitude to all teachers of the elementary school in Cibeber Community Health Center, students of Dental Education Bachelor Program Faculty of Medicine Universitas Jenderal Achmad Yani, and PT Unilever Indonesia, that have helped conducting this research.

\section{REFERENCES}

1. Dahl KE, Wang NJ, Holst D, Ohrn K. Oral health-related quality of life among adults 68-77 years old in Nord-Trondelag, Norway. Int J Dent Hyg Feb 2011;9(1):87-92 DOI: 10.1111/j.1601-5037.2010.00445.x.

2. National Institute of Health Research and Development (NIHRD). Indonesia Basic Health Research (RISKESDAS) 2007-2008. Jakarta: Ministry of Health Republic of Indonesia; 2008. p. 139-45.

3. Kidd EAM, Bechal SJ. Essentials of dental caries: the disease and its management. $2^{\text {nd }}$ ed. Bristol: IOP Publishing Ltd.; 2012.

4. Wong $\mathrm{DL}$, Hockenberry-Eaton $M$, Wilson $M$, Winkelstein ML, Schwartz P. Wong's clinical manual of pediatric nursing. $7^{\text {th }}$ ed. St. Louis, Mo.: Mosby Elsevier; 2008.

5. National Institute of Health Research and Development (NIHRD). Indonesia Basic Health Research (RISKESDAS) 2013. Jakarta: Ministry of Health Republic of Indonesia; 2013. p. 110118.

6. Edelstein BL. The dental caries pandemic and disparities problem. BMC Oral Health 2006;6(Suppl 1):S2. DOI: 10.1186/1472-6831. 6-S1-S2.

7. Pratiwi R, Mutmainnah R. Overview of severity of dental caries on 6,9 , and 12 years old children in Pinrang Regency, South Sulawesi using PUFA/pufa index. Dentofasial 2013;12(2):7680.

8. Liwe $M$, Mintjelungan $C N$, Gunawan $P N$. Prevalensi karies gigi molar satu permanen pada anak umur 6-9 tahun di Sekolah Dasar Kecamatan Tomohon Selatan. Jurnal e-GiGi 2015;3(2):416-20.

9. Premkumar S. Orthodontics - prep manual for undergraduates. $3^{\text {rd }}$ ed. Philadelphia: Elsevier Saunders, Mosby, Churchill; 2016. p. 110-118.

10. Sugiyono. Statistik untuk penelitian. $27^{\text {th }}$ ed. Bandung: CV. Alfabeta; 2016. p. 61-75.

11. Notoatmodjo S. Promosi Kesehatan dan Perilaku Kesehatan. $2^{\text {nd }}$ ed. Jakarta: EGC 1825; 2012. p. 55.

12. Lukacs JR. Fertility and agriculture accentuate sex differences in dental caries rates. Curr Anthropol 2008:49(5):901-14.

13. Fujita H, Asakura K, Ogura M. Age and sex-related dental caries prevalence in Japanese from the jomon period. J Oral Biosci 2007:49(3):198-204. DOI: 10.2330/joralbiosci.49.198.

14. Gayatri RW, Mardianto. Gambaran status karies gigi anak sekolah dasar kota Malang. J Preventia Jun 2016:1(1):42-50.

15. Heymann HO, Swift Jr. EJ, Ritter AV. Sturdevant's Art and Science of Operative Dentistry. $6^{\text {th }}$ ed. St. Louis: Mosby Elsevier; 2013. p. 41-3.

16. Kiswaluyo. Hubungan karies gigi dengan umur dan jenis kelamin siswa sekolah dasar di wilayah kerja Puskesmas Kaliwates dan Puskesmas Wuluhan Kabupaten Jember. Stomatognatic 2010:7(1):26-30.

17. Talibo RS, Mulyadi Ns, Bataha Y. Hubungan frekuensi konsumsi makanan kariogenik dan kebiasaan menggosok gigi dengan kejadian karies gigi pada siswa kelas III SDN 1 \& 2 Sonuo. J Keperawatan 2016:4(1):1-8. 